\title{
Madde Bağımlısı Bireylerin Yaşadığı Psikososyal Sorunlar, Uygulanan Kanıt Temelli Müdahaleler ve Hemșireliğin Rolü
}

\author{
Psychosocial Problems Experienced by Substance Addicts, Implemented Evidence- \\ Based Interventions and the Role of Nursing
}

\author{
(1) Seval CÜCELER ${ }^{1}$, (D) Mualla YILMAZ², (D Serpil TÜRKLEȘ ${ }^{2}$ \\ ${ }^{1}$ Toros Üniversitesi Hemşirelik Bölümü, Mersin, Türkiye \\ 2Mersin Üniversitesi Hemşirelik Bölümü, Mersin, Türkiye
}

\section{Öz}

Madde bağımlıı̆̆ı, bireyin sağlığını, aile hayatını, toplumun güvenliğini ve ekonomiyi de olumsuz yönde etkileyen önemli bir halk sağlı̆̆ı sorunudur. Madde bă̆ımlılı̆̆ ile mücadelede multidisipliner bir yaklașım gerekmektedir. Madde bağımlılığı; eğitim, ekonomi, sosyal ilișkiler ve damgalanma, duygusal ve psikiyatrik sorunlar gibi psikososyal boyutta birçok soruna neden olmaktadır. Bu derlemede madde bağımlılı̆ının psikososyal boyutları, birey ve ailenin psikososyal bakımında hemşirenin rolü, kanıta dayalı hemşirelik müdahaleleri ile neler yapılması gerektiği tüm boyutlarıyla aktarılmış, madde bağımlısı birey ve ailesine yönelik diğer disiplinler tarafından yapılan kanıt temelli müdahale çalışmalarından da örnekler sunularak konuya dikkat çekmek amaçlanmıştır.

Anahtar kelimeler: Madde bağımlılığı, psikososyal faktörler, hemşirelik, kanıta dayalı hemşirelik

\section{Abstract}

Substance addiction is an important public health problem that negatively affects the health of the individual, family life, the safety of the society and the economy. A multidisciplinary approach is required in the fight against substance addiction. Substance addiction causes many psychosocial problems such as education, economy, social relations and stigma, emotional and psychiatric problems. In this review, the psychosocial dimensions of substance addiction, the role of the nurse in the psychosocial care of the individual and the family, what should be done with the evidence-based nursing interventions are explained in all dimensions, and it is aimed to draw attention to the subject by presenting examples of evidence-based intervention studies conducted by other disciplines for the substance addicted individual and his family.

Keywords: Substance dependence, psychosocial factors, nursing, evidence-based nursing

\section{Giriş}

Madde bağımlılı̆̆ı, tüm dünyada olduğu gibi ülkemizde de toplum sağlığı açısından tehdit oluşturan, biyolojik, ruhsal ve sosyal boyutlarıyla toplumu etkileyen en önemli halk sağlığı sorunudur $(1,2)$. Birey, aile ve toplum üzerinde derin etkiler bırakan ve günümüzde önemli bir sosyal sorun haline gelen madde bağımlılı̆ı, günden güne artarak devam etmektedir (3). Madde bă̆ımlılığı yalnızca bireyin sağlığını değil, aynı zamanda aile hayatını, toplumun güvenliğini ve ekonomiyi olumsuz yönde etkilemesi, biyopsikososyal yönü olması nedeniyle mücadelede multidisipliner bir yaklașım gerektirir (4). Madde bağımlısı bireyler eğitim, aile, ruhsal, sosyal ve ekonomik olarak psikososyal boyutta birçok sorunla karşılaşmakta ve bireylerin yașam kalitesi olumsuz yönde etkilenmektedir $(5,6)$. Bu nedenle madde bağımlısı bireylerin yaşadığı psikososyal sorunların belirlenmesi ve bakımda bütüncül bir șekilde ele alınması oldukça önemli hale gelmektedir (6). Madde bağımlısı bireylerin yaşadığı psikososyal sorunların çözümüne yönelik 
kanıt temelli müdahale çalışmalarının yapılması son derece önemlidir. Bu nedenle madde bağımlısı bireyler için kanıta dayalı bakım uygulanmasına yönelik ilgi giderek artmaktadır. Madde bağımlılığına yönelik; bilişsel-davranışçı terapi (BDT), motivasyonel görüşme, alkol ve tütün kullanımı için kısa müdahaleler gibi psikososyal müdahaleler "kanıta dayalı" kabul edilmektedir (7). Madde bă̆ımlısı bireyler için kanıta dayalı bakım uygulanması hemşirelik disiplininin yanı sıra farklı disiplinler tarafından da gerçekleștirildiği, sürecin bir ekip hizmeti olduğu görülmektedir. Bu bağlamda bu derlemede madde bağımlıı̆ğının psikososyal boyutları, birey ve ailenin psikososyal bakımında hemşirenin rolü, kanıta dayalı hemșirelik müdahaleleri ile neler yapılması gerektiği tüm boyutlarıyla aktarılmıștır.

\section{Madde Bağımlıı̆ıııın Neden Olduğu Psikososyal Sorunlar}

Madde bağımlılığı, tıbbi sorunların yanı sıra iş gücü kaybı, mesleki problemler, evsizlik, toplumsal ve kișilerarası problemler gibi birçok sorunu beraberinde getiren ciddi sorunlardan biridir (6). Düşük benlik saygısı, kişilerarası sosyal ilişkilerde içe çekilme ya da bağımlı ilișkiler sergileme, duygularını aktaramama, anksiyete ve depresyon gibi birçok psikososyal soruna neden olmaktadır (4). Madde bağımlılı̆ı̆ın neden olduğu psikososyal sorun alanları aşağıda başlıklar halinde detaylandırılmıştır.

\section{Eğitim}

Madde bağımlılığı, bireylerin eğitim alanında çeşitli düzeylerde kayıplar yaşamasına neden olmaktadır. Özellikle eğitimleri yarım kalan ve diploma sahibi olamayan madde bağımlısı bireyler çoğu zaman potansiyellerinin altındaki işlerde düșük ücretle ve sosyal güvencesiz ișlerde çalıșabilmektedir. Bunun yanı sıra, okula devam eden madde kullanan öğrencilerin okul başarıları daha düşük ve okul devamsızıkları daha fazladır $(8,9)$. Yapılan bir araştırmada, madde bağımlısı olan bireyler ile olmayan bireyler arasında akademik performans açısından anlamlı fark olduğu saptanmış, madde kullanımı karşıtı kampanyaların sağlık eğitimi müfredatlarına dahil edilmesi önerilmiștir (10). Zayıf akademik performansın benlik saygısını azalttığı, bu durumun da benlik duygusunda karmaşaya yol açarak daha fazla madde tüketimine yol açabileceği ifade edilmektedir (11).

\section{Ekonomi}

Madde bağımlılığı, pek çok ülkede ekonomik alanda problemlere neden olan, bağımlı bireyin iş yaşamına ve içinde bulunduğu ülkenin ekonomisine ciddi hasarlar veren, bireyi ve ailesini ekonomik olarak zora sokan, mesleki kayıplara neden olan bir durumdur. Herhangi bir iște çalıșmayan madde bağımlısı bireyler, aileye ekonomik sorunlar yașatmakta ve ailenin yoksullaşmasına sebebiyet vermektedir $(6,12)$. Yapılan bir araştırmada madde bağımlıı̆ııın aileye, topluma ekonomik ve psikososyal yük getirdiği (13), alkol bağımlısı bireyler ile yapılan kalitatif bir araştırmada ise, bireylerin çoğunluğunun aile içi sermayelerini alkole harcamalarından dolayı mali durumlarının olumsuz yönde etkilendiği bildirilmiștir. Ayrıca alkol bağımlılığının maddi sorunlara yol açı̆ı̆ına vurgu yapılmaktadır (14). Bunun yanı sıra madde kullanımının iş bulma ve işi sürdürme şansını azalttığı düşünülmektedir (11). Madde bağımlısı bireyler ile yapılan bir araștırmada, alkol-madde kullanımı sonucu yaşanan iș kaybı çok yüksek oranda saptanmıș, bu durumun bireylerin ailelerinin de ciddi mağduriyet yaşadığını göstermesi açısından önemli olduğu ifade edilmiștir (15). Ayrıca madde bağımlısı olan bireyler meslek sahibi olamama, aynı iște sürekli çalıșamama ve ișten çıkarılma gibi sorunlarla karșı karşıya kalabilmektedir. Yapılan bir çalıșmada, madde bağımlılığının ișsizliğe neden olabileceği, madde bağımlısı bireylerin ișlerini kaybetme, iș bulma ve aynı iși sürdürmede problemler yaşayabileceği sonucuna varılmıștır (16). Sonuçta, meslek sahibi olamayan, olsa bile ișini kaybeden, tekrar iş bulma şansı azalan ve neticede ekonomik alanda kayıplar yaşayan madde bağımlısı bireylerin, baş etme yöntemi olarak tekrar madde kullanması kaçınılmaz bir hal alacaktır.

\section{Sosyal İlişkiler ve Damgalanma}

Madde bağımlılığı bireyin toplumdaki diğer insanlarla olan iletişimini tehlikeye atmaktadır. Bağımlılıkta madde kullanımı, bireylerin sosyal rol ve sorumluluklarını yerine getirmesini engellemekte, özdenetimlerini etkileyerek toplum tarafından kabul edilmeyen davranışlar sergilemelerine neden olabilmektedir. Bireyin sosyal ilișkileri, madde kullanımının bașlangıç evresinde çok fazla etkilenmezken, kronik madde kullanımında sosyal ilișkilerde bozulmalar bașlamaktadır. Çaresizlik ve yetersizlik duyguları yașayan bireyler toplumdan kendilerini soyutlayarak yalnızlaşabilirler $(6,12)$. Madde bağımlısı olan ve olmayan bireylerle yapılan bir araștırmada, madde bağımlısı bireylerde yalnızlık hissinin madde bağımlısı olmayanlara kıyasla daha güçlü olduğu ortaya konmuştur (17). Bunun yanı sıra, madde bağımlısı bireylerin sosyal dışlanma açısından yüksek riskli gruplar arasında olduğu ifade edilmektedir (12). Madde bağımlılığı tanısı almış bireylerle yapılan bir araștırmada, madde kullanımı sebebiyle sosyal olarak dıșlandığını düșünenlerin oranı \%84 olarak bulunmuştur (18). Madde bağımlılığı tedavisi gören kișiler ile yapılan nitel bir çalıșmada, çalıșmaya katılan bireyler madde kullandıkları süre zarfında toplum tarafından etiketlenme ve dıșlanma gibi sorunlar yaşadığını ifade etmişlerdir (19). Bağımlı bireylerin yaşadığı bu ayrımcılık ve damgalanma, bireyin toplumdan uzaklașmasına ve kișiler arası ilișkilerde çatışmalar yașamasına neden olmaktadır. Birey yașadığı bu sosyal sorunlarla bașa çıkabilmek için ise tekrar alkol ve maddeye yönelerek kısır döngü içerisine girmektedir (6,20). Madde bağımlılığı ayrıca, bireylerin evlerini kaybetmesine ve sokakta yaşamasına neden olabilmektedir. Toplum ise evsizliği, istenmeyen sosyal bir sorun 
olarak görmekte ve evsiz bireyleri sorumsuz, iş, aile ve toplumla bağı olmayan, tehlikeli olarak damgalamaktadır (21). Madde bağımlısı bireyler, hem madde bağımlısı hem de evsiz olduğu için damgalanabilmekte, bu da bireylerin toplumdan kendini tamamen soyutlamasına neden olabilmektedir.

\section{Aile}

Madde kullanımı ve aile ile ilişkili literatürün genel olarak bireyin madde kullanmaya başlamasında ailenin rolü noktasına ağırlık verdiği, bağımlı bireylerin aile üzerindeki etkisi konusunun göz ardı edildiği ifade edilmektedir. Oysa madde kullanımı bütün aile üzerinde etkili olmakta ve madde bağımlılığı, aile içinde ortaya çıkmasının yanı sıra evlilik ilişkileri, aile içi şiddet, çocuk istismarı ve ihmali üzerindeki etkileri göz önünde bulundurulduğunda bir aile sorunu olarak karșımıza çıkmaktadır $(22,23)$.

Bă̆ımlı bireylerveailelerisıklıkla; aile içişiddet olaylarında artma, eșler arasında anlașmazlıklar ya da evliliğin devam etmemesi ve aile yaşamının bozulması gibi zorluklarla karşılașmaktadır (6). Yapılan bir araştırmada, alkol bağımlısı erkeklerin eșlerinin aile içi șiddet (sözel ve fiziksel) ve ailede iletişim problemleri yaşadıkları ortaya konmuş, yardım ve danışmanlığa ihtiyaç duydukları belirlenmiștir (24). Madde bağımlılığı, aile üyeleri arasında gerginliklere ve çatıșmalara sebep olmaktadır. Örneğin, madde kullanan aile üyesinin, eve istenmeyen arkadaşlarını getirmesi çatıșmalara neden olmakta, bağımlı bireyin çeșitli sebeplerle ailesine yalan söylemesi ve onlara karșı saldırgan davranıșlarda bulunması aile içinde gittikçe derinleșen yaralar açmaktadır $(25,26)$. Madde bağımlısı adölesanların ebeveynleri ile yapılan kalitatif bir çalışmada, ebeveynler, çocuklarının arkadaș çevresinin değiștiğini, çocuklarının bu yeni arkadașlarını kendilerinden uzak tuttuğunu ifade etmișlerdir. Yine aynı çalıșmada, ebeveyn ve adölesanlar arasındaki ilișkide, çı̆̆lık atma, bağırma gibi davranışların aile ilișkilerinin bir parçası haline geldiği saptanmıștır (27). Görüldüğü üzere madde bağımlılığı, aile içi iletişim süreçlerini olumsuz etkilemekte, birçok çatıșma ve sorunları beraberinde getirerek ailede yıkıma neden olmaktadır. Ayrıca, ailede madde bağımlısı birinin varlığı diğer aile üyeleri üzerinde duygusal yüke neden olabilmekte, aile üyeleri hayal kırıklığı, utanç ve suçluluk, korku, endișe ve öfke gibi duygular yaşayabilmektedir (25). Yapılan bir araştırmada, madde bağımlısı olan bireylerin ebeveynlerinde öfke, anksiyete ve depresyon düzeylerinin sağııkı kontrol grubuna kıyasla daha yüksek olduğu ortaya konmuştur (28).

Madde bağımlısı birey ailesi üzerinde olumsuz etkiler yarattı̆̆ı gibi madde bağımlısı ebeveynler de çocukları üzerinde kalııı etkiler bırakabilmektedir. Bağımlı bireylerin çocuklarında bilișsel ișlevlerinin daha düșük olduğu, depresyon, anksiyete ve düșük öz güven gibi psikolojik problemlerin sık görüldügü ve bu çocuklarda yalan söyleme, hırsızlık yapma ve kavga etme gibi davranışsal sorunların var olduğu ifade edilmektedir $(22,29)$. Tüm aileyi derinden etkileyen bu durum, madde bağımlısı bireylerin hemşirelik bakımına, ailenin de dahil edilmesinin gerekliliğini ortaya koymaktadır.

\section{Psikiyatrik ve Psikolojik Sorunlar}

Madde ile ilișkili bozukluklar ve psikiyatrik bozukluklar bir arada seyredebilmektedir. Ruhsal bozukluğu olan bireyler kendi kendini tedavi etme amacıyla madde kullanabileceği gibi, madde bağımlılığı nedeniyle de ruhsal bozukluklar gelișebilmektedir $(6,30)$. Yapılan bir araştırmada, madde kullanım problemi olan bireylerde eş zamanlı olarak ruhsal problemlerin yaygın olarak görüldüğü bildirilmiștir (31). Ruhsal bozuklukların bağımlııı ile beraber görülmesi ise prognozu olumsuz etkilemekte ve bu yüzden de komorbitenin tanılanması ve ele alınması önem taşımaktadır (6).

Madde bağımlılığı ve depresyon sık görülen hastalıklar arasında olup birlikte de görülebilmektedir (26). Yapılan bir çalıșmada, araștırmaya katılan madde bağımlısı bireylerin \%73.8'inin depresyon olduğu saptanmıștır (32). Madde bağımlısı olan bireylerle yapılan bir diğer araştırmada ise, madde bağımlısı olan bireylerin kontrol grubuna göre daha yüksek düzeyde depresyon ve anksiyete bildirdiği ortaya konmuş, madde bă̆ımlısı olan bireylerde depresyon ve anksiyete prevelansının yüksek olduğu ve sıklıkla bir arada görüldüğü sonucuna varılmıștır (33). Bunun yanı sıra, madde bağımlısı olan bireylerde öfke ve saldırganlık davranıșlarının görüldügü de bildirilmektedir (34). Laitano ve arkadașları yaptıkları (2021) bir sistematik derleme ve metaanaliz çalışmasında, psikoaktif madde kullanan bireylerin kullanmayanlara kıyasla daha yüksek düzeyde öfkeye sahip olduğunu ortaya koymuş ve tedavi programlarında öfke yönetiminin de ele alınmasını önermiștir (35). Ayrıca, madde kullanımı bireyleri intihar davranıșına itmektedir (4). Yapılan bir araştırmada madde bağımlısı olan bireylerde intihar davranışı öyküsü bulunduğu ortaya konmuștur (36). Madde bağımlısı olan bireylerin düşük benlik saygısına sahip olduğu ve benlik saygısı intiyacını giderebilmek içinde madde kullanma eğiliminde olduğu aktarılmaktadır (4). Görüldüğ̈ü üzere, madde bağımlıı̆̆ı, bireylerin ruh sağlı̆̆ı üzerinde de ciddi hasarlar oluşturabilmekte ve yaşamı üzerinde olumsuz etkiler bırakabilmektedir. Bu nedenle madde bağımlısı bireylere bakım veren hemșireler, bireylerin ruh sağlı̆̆ını da değerlendirmeli ve psikososyal bir bakım sunmalıdır.

\section{Psikososyal Hemşirelik Bakımı ve Kanıt Temelli Müdahale Çalışmaları}

\section{Psikososyal Hemşirelik Bakımı}

Psikososyal bakım, hastalığın emosyonel yönüyle baş etme güçlüğü yaşayan, sağlığı ve sağıık bakımını etkileyen yașam 
krizleri olan ve ruhsal bozukluğa sahip bireylere yardımı ifade etmekte, birey ve ailenin intiyaçlarına odaklanmaktadır (37). Madde bağımlılı̆ı psikososyal boyutu olan bir sağlık problemi olup disiplinler arası yaklaşım gerektirmektedir $(4,38)$. Tedavi ekibi içerisinde, madde bağımlısı olan bireylerle en çok vakit geçiren ve onlara psikososyal müdahaleleri uygulayan sağlık profesyonelleri ruh sağ Iığı ve psikiyatri hemșireleridir. Ekip içinde hemșire, bütüncül bakım anlayıșıyla hareket ederek hem bireye hem de bireyin ailesine ve çevresine hizmet sunmaktadır $(6,38)$.

Hemşire madde bağımlısı bireye bakım verirken, hemşirelik sürecini itina ile kullanmalıdır. Birey ve ailesinin fiziksel ve psikososyal tanılamasını yaparak bakım gereksinimlerini ve bu doğrultuda kısa ve uzun vadeli amaçları belirlemeli, hemşirelik girişimlerini planlamalı, uygulamalı ve elde ettiği verileri değerlendirmelidir. Madde kullanımının neden olduğu sorunları değerlendirmeli ve bakım sürecinde ele almalıdır. $(4,38,39)$. Bireyin madde bağımlılı̆ı nedeniyle ailesi ile yașadığı sorunlara yönelik, bireyin aile ilișkilerini analiz etmeli, ailenin tedavi ve bakım sürecine katılımını sağlamalıdır. Birey ve aileye yönelik eğitimler düzenlemeli, eğitimde bağımlılığının bir hastalık olduğu, geçmişteki etkisiz baş etme yöntemleri yerine etkili yöntemlerin geliştirilebileceği, tedavi sonrası programlara katılımın önemi gibi konular vurgulanmalıdır $(26,38)$. Bireyin madde bağımlılı̆̆ nedeniyle yaşadığı ruhsal sorunları değerlendirmeli, benlik saygısı ve stresle bașa çıkma gibi konuları, homisid (başkasını öldürme) ve suisid (intihar, özkıyım) risklerini hemșirelik bakımında ele almalıdır. Hemșire, bireyin madde bağımlılı̆̆ nedeniyle yaşadığı sosyal sorunları değerlendirmeli (sosyal destek düzeyi, sosyal ilișkiler ve roller vb) ve öfke kontrolü, problem çözme, iletişim gibi sosyal beceri gruplarına katııımını sağlamalıdır (6,26). Ayrıca, bireylerin sosyalizasyonunu sağlayacak, benlik saygılarını ve girișimciliğini arttıracak terapötikgrup çalışmalarını (günaydın, işe yönlendirme vb) düzenlemeli ve katıımlarını teșvik ederek gözlemlemelidir. Bunların dışında madde bağımlısı bireylere bakım veren hemșireler, bağımlı bireye karșı tutum ve ön yargılarının fakında olmalı ve olumsuz tutumlardan kaçınmalıdır. Bağımlıık hakkında bilgi düzeyini arttırmalı, araştırmalar yaparak mesleki gelişimine katkı sağlamalıdır $(4,6,39,40)$.

\section{Hemşirelik ve Diğer Disiplinler Tarafından Yapılan Kanıt Temelli Müdahale Çalışmaları}

Madde bağımlısı bireylerin yaşadığı psikososyal sorunların çözümüne yönelik; bireyin sosyal ișlevselliğini ve yașam kalitesini iyileștirmek, nüks ve yeniden hastaneye yatışları azaltmak amacıyla, tedavide çeşitli psikososyal müdahaleler uygulanmaktadır (41). Bilişsel davranışsal terapi (BDT), kısa girișimler, kısa süreli terapiler, madde bağımlılığı danıșmanlığı, motivasyonel görüşmeler, grup psikoterapisi, aile terapisi, kendine yardım grupları, nüks önleme gibi müdahaleler madde bağımlılığı tedavisinde kullanılan psikososyal müdahalelerdendir $(26,42)$.

Literatürde, hemşire araştırmacılar tarafından, madde bağımlılığı olan bireyler ve bu bireylerin ailesine yönelik psikososyal müdahaleler kullanılarak yapılmış kanıt temelli müdahale çalıșmaları mevcuttur $(43,44,45)$. Örneğin, Karimi ve arkadaşları (2019) madde bağımlısı bireylerin bakım verici aileleriyle yaptıkları randomize kontrollü çalışmada; yaşam kalitesi temelli grup danışmanlığı müdahalesinin, bakım verici ailelerin stres ve yaşam doyumları üzerindeki etkililiğini test etmiş ve çalışma sonucunda müdahalenin bakım vericilerin stres şiddetinin azaltılması ve yaşam doyumunun iyileștirilmesi üzerinde önemli ölçüde olumlu etki yarattığını saptamıştır (43). Bir bașka hemșire araștırmacıların, alkol bağımlısı bireyler ile yaptıkları randomize kontrollü çalıșmada; taburculuk öncesi başlatılan ve taburculuktan sonra da sürdürülen motivasyonel görüșmeye dayalı kısa müdahalenin, taburculuk sonrasında kısa vadede alkolden uzak durma sıklığını arttırmada etkili olduğunu ortaya koymuştur (44). Zhuang ve arkadaşları bilişsel davranışsal müdahalelerin Çinli eroin bağımlılarında yaşam kalitesini iyileștirip iyileștirmeyeceğini belirlemek amacıyla yaptıkları randomize kontrollü çalıșma sonucunda, Çinli eroin bağımlılarının yaşam kalitesi ve sağlık durumunun, hemşire tarafından yönetilen bir bilişsel davranışçı müdahale gördükten sonra iyileștiğini tespit etmiștir (45).

Bunların dışında, bazı tamamlayıcı terapilerin hemşire araștırmacılar tarafından kullanıldığı görülmektedir. Ng ve ark. (2020) yaptıkları randomize kontrollü çalıșmada; hemşire liderliğindeki beden-zihin-ruh (BMS) temelli nüks önleme müdahalesinin alkol bağımlısı bireyler arasında aşerme ve alkol tüketiminin miktarı ve sıklığı üzerindeki etkinliğini değerlendirmeyi amaçlamış, üç aylık takip sonunda deney grubunun kontrol grubuna kıyasla önemli ölçüde daha az alkol tüketimi, daha az içme günü, daha düşük relaps oranları ve daha az așerme bildirdiğini ortaya koymuștur (46). Hemșire araștırmacılar tarafından yapılan bir bașka randomize kontrollü pilot çalışmada ise, çok adımlı bir bitkisel sigara bırakma rejiminin etkinliğini test etmiş ve daha büyük bir denemenin garanti edilebileceği, bitkisel formüllerin etkinliğini değerlendiren daha fazla çalışmaya intiyaç olduğu sonucuna ulaşmıştır (47).

Literatür gözden geçirildiğinde, psikososyal sorunların çözümüne yönelik madde bağımlısı birey ve ailesine uygulanan kanıt temelli müdahale çalışmalarının farklı disiplinler tarafından gerçekleștirildiği görülmektedir. Doktor ve psikolog araştırmacılar tarafından 2021 yılında yapılan pilot randomize klinik çalışmada, madde bağımlısı olan ergenlerin tedavisine ebeveyn katılımını kolaylaşırmak için oluşturulan teknoloji destekli bir müdahalenin (ebeveyn SMART) uygulanabilirve kabul edilebilir olduğunu kanıtlanmış, ebeveynleri teknoloji destekli 
müdahale alan madde bağımlısı ergenlerin, alkol aldığı gün sayısının azaldığı ve okulla ilișkili daha az sorun yașadığı ortaya konmuştur (48). Psikiyatristler tarafından yapılan randomize klinik araştırmada ise, İspanyolca konuşan madde bağımlısı bireylerin standart tedavisine kültüre uyarlanmış web tabanlı bilișsel davranıșçı terapi eklenmiş ve sonuçta bu yaklaşımın madde kullanım sonuçlarını iyileștirdiği ortaya konmuștur (49). Psikologlar ise yaptıkları randomize kontrollü çalıșmada, farkındalık temelli yogik solunum müdahalesinin sigara içme arzusu, yoksunluk, duygulanım ve sigara içme davranıșı üzerindeki etkilerini incelemiş, bu müdahalenin özellikle sigarayı bırakmanın akut olumsuz etkilerini hafifletmede ve sigara içme davranışını azaltmada etkili olduğunu saptamıştır (50). Psikolog araștırmacıların yaptığı bir başka randomize klinik çalışmada ise, madde bağımlılı̆ı̆ ve intihar eğilimi olan ergenler için bir bilişsel davranışçı tedavi (BDT) protokolü test edilmiș ve çalıșma sonucunda, entegre BDT alan ergenlerin madde kullanımı ve intihar davranıșında anlamlı iyileșme görüldüğü, psikiyatrik tedavi için yatıșlar ve acil servis ziyaretleri dahil olmak üzere ek sağlık hizmetlerinin kullanımında belirgin bir azalma olduğu ortaya konmuștur (51). Doktor ve psikologlar tarafından yapılan bir bașka randomize kontrollü çalıșmada da, sosyal anksiyete ve alkol kullanım bozukluğu komorbiditesi için entegre BDT ve motivasyon geliștirme terapisinin, standart alkol bağımlılığı odaklı tedaviye göre sonuçları iyileștirip iyileștirmediği değerlendirilmiş, entegre tedavinin yaşam kalitesini ve sosyal anksiyete bozukluğu semptomlarında iyileșmeyi artırdığı saptanmıștır (52). Spor bilimlerinden araștırmacılar tarafından yapılan randomize kontrollü çalıșmada ise, madde bağımlılığında aerobik egzersiz eğitiminin madde kullanım isteğini azalttığı kanıtlanmıştır (53). Psikiyatri, psikoloji ve sosyal hizmet alanlarından araștırmacıların yaptığı randomize kontrollü çalıșmada ise, madde bağımlılığının yaygınlığını azaltmada çok boyutlu aile terapisinin bireysel psikoterapiden daha etkili olduğunu bildirmiş̧tir (54). Farklı disiplinler tarafından madde bağımlısı birey ve ailesine yönelik psikososyal müdahale kullanılarak yapılan kanıt temelli müdahale çalıșmalarında, psikososyal müdahalelerden BDT'nin daha sık kullanıldığı göze çarpmaktadır. Bunun yanı sıra tamamlayıcı terapilere daha az yer verildiği ve özellikle yaratıı sanat terapilerinin neredeyse hiç kullanılmadığı dikkat çekmektedir.

\section{Sonuç}

Madde bağımlılığı biyopsikososyal boyutu olan, birey ve çevresi üzerinde derin yaralar bırakabilen bir sağlık sorunudur. Incelenen araştırmalar göz önünde bulundurulduğunda, madde bağımlısı bireylerin yaşadığı psikososyal sorunların çözümüne yönelik uygulanan kanıt temelli müdahale çalıșmalarının hemşireliğin yanı sıra farklı disiplinler tarafından da gerçekleștirildiği, sürecin bir ekip hizmeti olduğu görülmektedir.
Madde bağımlısı bireylere bakım veren ve ekibin önemli bir parçası olan hemşireler, psikososyal bakım yapabilmek için motivasyonel görüşme teknikleri, BDT, aile terapisi gibi eğitimler almalı ve psikososyal sorunların çözümüne yönelik kanıt temelli hemşirelik müdahalelerini bakımda kullanmalıdır. Bu bağlamda, hemşirelik alanında madde bağımlısı birey ve ailesine yönelik kanıt temelli müdahale çalışmalarının arttıııması önerilmekte, kanıt temelli müdahalelerin madde bağımlısı birey ve ailesinin yaşam kalitesini olumlu yönde etkileyeceği düşünülmektedir.

\section{Kaynaklar}

1. Albayrak S, Balcı S. Gençlerde madde bağımlılığı ve önlenmesi. Hemșirelikte Eğitim ve Araștırma 2014; 11(2): 30-37.

2. T.C. Sağlık Bakanlığı Sağlık Hizmetleri Genel Müdürlüğü. Madde Bağımlılığı Tanı Ve Tedavi Kılavuzu El Kitabı. Ankara: T.C. Sağlık Bakanlığı, 2012.

3. Ișık A. Türkiye'de madde bağımlılığıyla mücadelede bir sosyal politika uygulaması olarak okul sosyal hizmetinin önemi. Toplum ve Sosyal Hizmet 2018; 29(1): 208-228.

4. Karakaș SA, Ersöğütçü F. Madde bağımlılığı ve hemșirelik. Sağlık Bilimleri ve Meslekleri Dergisi 2016; 3(2): 133-139.

5. Sahu KK, Sahu S. Substance abuse causes and consequences. Bangabasi Academic Journal 2012; 9: 52-59.

6. Dikeç G, Kutlu FY. Dezavantajlı gruplar olarak bağımlıların psikososyal sorunları. Yılmaz M (editör). Dezavantajlı Gruplar ve Ruh Sağlığı. 1. Baskı. Ankara: Türkiye Klinikleri, 2020: 50-55.

7. Jhanjee S. Evidence based psychosocial interventions in substance use. Indian J Psychol Med 2014; 36 (2): 112-118.

8. Şener TA, Erdem E. Çocuk ve ergenlerde madde bağımlılığı. Polat S(editör). Çocukluk Çağında Sık Karşılașılan Adli Sorunlar ve Hemșirelik Yönetimi. 1. Baskı. Ankara: Türkiye Klinikleri, 2020:18-24.

9. Gökler R, Koçak R. Uyuşturucu ve madde bağımlılı̆̆ı. Sosyal Bilimler Araștırmaları Dergisi 2008; 3(1): 89-104.

10. Akanbi MI, Augustina G, Theophilus AB, et al. Impact of substance abuse on academic performance among adolescent students of colleges of education in Kwara state, Nigeria. Journal of Education and Practice 2015; 6(28): 108112.

11. United Nations Office on Drug and Crime. Economic and social consequences of drug abuse and illicit trafficking. New York: United Nations, 1998.

12. Derin M, Tapan MG. Madde bağımlı̆̆ı ve sosyal dıșlanma. Tıbbi Sosyal Hizmet Dergisi 2017; (10): 26-36.

13. Gümüş Ö, Şahin E, Top MȘ. Alkol ve eroin bağımlılarının ailelerindeki psikososyal ve ekonomik zorlukların araștırılması. Bağımlılık Dergisi 2002; 3(3): 146-154.

14. Nadkarni A, Dabholkar H, McCambridge J, et al. The explanatory models and coping strategies for alcohol use disorders: an exploratory qualitative study from India. Asian J Psychiatr 2013; 6(6): 521-527.

15. Asan Ö, Tıkır B, Okay IT, Göka E. Bir AMATEM birimine başvuran alkol ve madde kullanım bozukluğu olan hastaların sosyodemografik ve klinik özellikleri. Bağımlılık Dergisi 2015; 16(1): 1-8.

16. Henkel D. Unemployment and substance use: a review of the literature (1990-2010). Curr Drug Abuse Rev 2011; 4(1): 4-27.

17. Hosseinbor M, Ardekani SMY., Bakhshani S, Bakhshani S. Emotional and social loneliness in individuals with and without substance dependence disorder . Int J High Risk Behav Addict 2014; 3(3): e22688. 
18. Soy IT, Kocataş S. Madde bağımlıı̆̆ı tanısı almış bireylerde benlik saygısı ve sosyal dıșlanma algıları arasındaki ilișki. Ege Üniversitesi Hemșirelik Fakültesi Dergisi 2020; 36(2): 73-86.

19. Akbaş GE., Mutlu E. Madde bağımlılığı tedavisi gören kișilerin bağımlılık ve tedavi deneyimleri. Toplum ve Sosyal Hizmet 2016; 27(1): 101-122.

20. Yılmaz M, Cüceler S. Alkol bağımlı̆ı ve damgalanma. Bağımlılık Dergisi 2019; 20(3): 167-174.

21. Belcher JR., DeForge BR. Social stigma and homelessness: The limits of social change. J Hum Behav Soc Environ 2012; 22(8): 929-946.

22. Taylan HH. Madde bağımlılığı sürecinde ailenin rolü. Genç Y (editör). Madde Bağımlılığı ve Aile. Ankara: Akademisyen Kitabevi, 2018: 12-31.

23. Gruber KJ, Taylor MF. A family perspective for substance abuse: implications from the literature. J Soc Work Pract Addict 2006; 6(1-2): 1-29.

24. Korkmaz G, Batur D, Karakuş E, Tel H. Alkol bağımlısı erkeklerin eşlerinin yașadıkları güçlükler ve bașetme tarzlarının belirlenmesi. CÜ Hemşirelik Yüksek Okulu Dergisi 2003; 7(1): 21-26.

25. Daley DC. Family and social aspects of substance use disorders and treatment. J Food Drug Anal 2013; 21(4): S73-S76.

26. Ögel K. Sigara, Alkol ve Madde Kullanım Bozuklukları: Tanı, Tedavi ve Önleme. İstanbul: Yeniden Yayınları, 2010:3-4.

27. Choate PW. Adolescent alcoholism and drug addiction: The experience of parents. Behav Sci (Basel) 2015; 5(4): 461-476.

28. Ekinci S, Yalçınay M, Kural HU, Kandemir H. Madde bağımlılığı olan hastaların ebeveynlerinde öfke düzeyi: öfkenin, depresyon ve anksiyete düzeyi ile ilișkisi. Klinik Psikiyatri Dergisi 2016; 19(3): 125-129.

29. Substance Abuse and Mental Health Services Administration Center for Substance Abuse Treatment. Substance Abuse Treatment and Family Therapy. Rockville, MD: U.S. Department Of Health and Human Services, 2005

30. Karaoğlan M, Kaşarcı G, Şahin E, İplik ES. Madde ilişkili psikotik bozuklukların tedavisinde kullanılan atipik antipsikotikler. Experimed 2020; 10(1): 49-58.

31. Kuussaari K, Karjalainen K, Niemelä S. Mental health problems among clients with substance use problems: a nationwide time-trend study. Soc Psychiatry Psychiatr Epidemiol 2020; 55(4): 507-516.

32. Pradhan SN, Sharma SC, Shrestha MR, Shrestha S. A study of depression among patients of substance use disorder. Journal of Kathmandu Medical College 2012; 1(2): 96-99.

33. Mohamed II, Ahmad HEK, Hassaan SH, Hassan SM. Assessment of anxiety and depression among substance use disorder patients: a case-control study. Middle East Curr Psychiatry 2020; 27: 22.

34. Czermainski FR, Lopes FM, Ornell F, et al. Concurrent use of alcohol and crack cocaine is associated with high levels of anger and liability to aggression. Subst Use Misuse 2020; 55(10): 1660-1666.

35. Laitano HV, Ely A, Sordi AO, et al. Anger and substance abuse: a systematic review and meta-analysis. Braz J Psychiatry 2021; doi: 10.1590/1516-44462020-1133.

36. Cantão L, Lappann Botti NC. Suicidal behavior among drug addicts. Rev Bras Enferm 2016; 69(2): 366-373.

37. Kocaman N. Konsültasyon liyezon psikiyatrisi hemşireliği ve genel hastanede psikososyal bakım. Türkiye Klinikleri Dahili Tıp Bilimleri Psikiyatri Konsültasyon Liyezon Psikiyatrisi Özel Sayısı 2006; 47: 97-107.

38. Şimșek N. Madde kullanım bozukluğu olan birey ve ailesinin hemşirelik bakımı. Psikiyatri Hemșireliği Dergisi 2010; 1(2): 96-99.
39. Evli M, Albayrak E. Madde bağımlılığında hemșirelik. ERÜ Sağlık Bilimleri Fakültesi Dergisi 2020; 7(2):10-14.

40. Sağık Bakanlığı. Hemşirelik yönetmeliğinde değişiklik yapılmasına dair yönetmelik. https://www.resmigazete.gov.tr/eskiler/2011/04/20110419-5. htm (26 Nisan 2021'de ulaşıldı).

41. Imkome EU. Nursing Care for Persons with Drug Addiction. Zhao F, Li M (editors). Drug Addiction. London: Intech Open, 2018: 49-72.

42. Dönmez A. Tamamlayııı, Somatik ve Yaratıcı Terapiler. Çam O, Engin E (editörler). 3. Baskı. Ruh Sağlığı ve Hastalıkları Psikiyatri Hemşireliği Bakım Sanatı. İstanbul: İstanbul Tıp Kitabevleri, 2021: 968-977.

43. Karimi Z, Rezaee N, Shakiba M, Navidian A. The effect of group counseling based on quality of life therapy on stress and life satisfaction in family caregivers of Individuals with substance use problem: a randomized controlled trial. Issues Ment Health Nurs 2019; 40(12): 1012-1018.

44. Bager P, Vilstrup H. Post-discharge brief intervention increases the frequency of alcohol abstinence-a randomized trial. J Addict Nurs 2010; 21(1): 37-41.

45. Zhuang SM, An SH, Zhao Y. Effect of cognitive behavioural interventions on the quality of life in Chinese heroin-dependent individuals in detoxification: a randomised controlled trial. J Clin Nurs 2014; 23(9-10): 1239-1248.

46. Ng SM, Rentala S, Chan CL, Nayak RB. Nurse-led body-mind-spirit based relapse prevention intervention for people with diagnosis of alcohol use disorder at a mental health care setting, India: a pilot study. J Addict Nurs 2020; 31(4): 276-286.

47. James GD, Britton G R, Sobczak J, et al. A pilot randomized, placebocontrolled, double-blind trial of a multistep herbal program for assisting smokers to quit. J Addict Nurs 2012; 23(4): 231-240.

48. Becker SJ, Helseth SA, Janssen T,et al. Parent SMART (substance misuse in adolescents in residential treatment): Pilot randomized trial of a technologyassisted parenting intervention. J Subst Abuse Treat 2021; 128: 108457.

49. Paris M, Silva M, Añez-Nava L, et al. Culturally adapted, web-based cognitive behavioral therapy for Spanish-speaking individuals with substance use disorders: A randomized clinical trial. Am J Public Health 2018; 108(11): 1535-1542.

50. Lotfalian S, Spears CA, Juliano LM. The effects of mindfulness-based yogic breathing on craving, affect, and smoking behavior. Psychol Addict Behav 2020; 34(2): 351-359.

51. Esposito-Smythers C, Spirito A, Kahler CW, et al. Treatment of co-occurring substance abuse and suicidality among adolescents: a randomized trial. J Consult Clin Psychol 2011; 79(6): 728-739.

52. Stapinski LA, Sannibale C, Subotic M,et al. Randomised controlled trial of integrated cognitive behavioural treatment and motivational enhancement for comorbid social anxiety and alcohol use disorders. Aust N Z J Psychiatry 2021; 55(2): 207-220.

53. Wang D, Zhu T, Zhou C, Chang YK. Aerobic exercise training ameliorates craving and inhibitory control in methamphetamine dependencies: a randomized controlled trial and event-related potential study. Psychol Sport Exerc 2017; 30: 82-90.

54. Rigter $\mathrm{H}$, Henderson CE, Pelc I, et al. Multidimensional family therapy lowers the rate of cannabis dependence in adolescents: A randomised controlled trial in Western European outpatient settings. Drug Alcohol Depend 2013; 130(1-3): 85-93. 